\title{
Determination of Dominant Factors Diamond Fraud at Drinking Water Company
}

\author{
Hermansyah \\ Magister Management Student, Mercubuana University, Jakarta, Indonesia
}

M. Ali Iqbal

Senior Lecturer in Magister Management Program, Mercubuana University, Jakarta, Indonesia

Ahmad Badawi Saluy

Senior Lecturer in Magister Management Program, Mercubuana University, Jakarta, Indonesia

\begin{abstract}
Research with the title Determination Factors Dominant of Diamond Fraud at Drinking Water Company with the aim to find out, describe, measure and analyze the influence of diamond fraud variables (capability, pressure, rationalization and opportunity) at Drinking Water Company The subject of this study was the Directorate of Services and Managing Water Use with the number of employees as 203 people. The data obtained were analyzed using SEM (Structural equation modeling is a statistical technique used to build and test statistical models that are usually in the form of causal models. The software used in this SEM analysis is LISREL 8.8. The results of the overall research, conceptualization and prevention of fraud through capability, pressure, rationalization and pelaang at Drinking Water Company shows that pressure is no longer a variable that has a relationship or influence on fraud variables. It is recommended to management to develop a system of controlling and monitoring opportunities that cause fraud that can arise from factors of capability, opportunities, rationalization. One of the management systems that can be applied to fraud control is the application of ISO37001: 2016 or what is known as an anti-bribery management system.
\end{abstract}

Keywords: capability, rationalization, pressure, opportunities.

DOI: $10.7176 / \mathrm{EJBM} / 12-33-07$

Publication date: November $30^{\text {th }} 2020$

\section{Introduction}

1.1. Research background

Regional Water Supply Company which later became known as PDAM is a regional company that has duties and responsibilities in the provision of clean water for the surrounding community by prioritizing K4 (quality, quantity, continuity and affordability). Quality means that companies must be able to produce products according to clean water acceptability standards, quantity means that companies must ensure water pressure of at least 1 psia, continuity means that the organization must ensure that water lives within 24 hours, affordability means having tariffs that are affordable by the community.

Based on data from the Ministry of Public Works and Public Housing (PUPR) through the Agency for the Improvement of Drinking Water Supply System (BPPSPAM) states that there are 374 PDAMs in Indonesia as of December 6, 2018 .

In accordance with article 1 paragraph 1 of Law No. 25 of 2009 concerning public services stated that public services are activities or series in the framework of meeting service needs in accordance with the laws and regulations for every citizen and resident of goods, services and / or administrative services provided by public service providers. Based on this understanding, PDAM public service activities have been regulated fulfillment is based on regulations made by the government with the main objective to meet basic needs and welfare of the community.

Among them:

- Law number 8, 1999 concerning Consumer Protection (State Gazette of the Republic of Indonesia Number 42 of 1999, Supplement to the State Gazette of the Republic of Indonesia Number 3821); the point is to explain that the rights of consumers include the right to comfort, security and safety in consuming goods and or services ; the right to choose goods and or services and to obtain said goods and or services in accordance with the exchange rate and conditions and guarantees promised; the right to be treated or served properly and honestly and not discriminatory; the right to receive compensation, compensation and or replacement, if the goods and or services received do not comply with the agreement or are not as intended

- Law number 28, 1999, concerning the administration of a state that is clean and free of Corruption, Collusion and Nepotism (State Gazette of the Republic of Indonesia Year 1999 Number 75, Supplement to the State Gazette of the Republic of Indonesia Number 3851);

- Law Number 5, 1962 concerning Regional Enterprises (State Gazette of the Republic of Indonesia of 1962 
Number 178, Supplement to the State Gazette of the Republic of Indonesia Number 2094).

One of the target/KPI in addition to a profit and coverage area of service is the customer growth and maintain the number of active customers. To achieve this, there needs to be a structural function, namely the Service and Manage Water Use. In accordance with PDAM business process mapping, the service function is to ensure customer growth and customer satisfaction levels, while Manage Water Use functions to supervise customers who have problems, such as arrears in payment of water accounts, removal of water meters and others that are not in accordance with the contract have already been signed.

In carrying out their duties and responsibilities, these two functions will be very touching with prospective or active customers. Starting from the survey for the installation of new connections to the customer connection termination. In this process will be a lot of potential violations of the laws and codes of conduct, such violations then known with the term fraud.

The problem of fraud is a problem that often occurs in the back of any world. If we look at the macro, that in developed countries with a stable economic life, fraud practices tend to have a little mode of doing. As for developing countries like Indonesia, fraud practices tend to have many modes to do. Fraud can occur in the private, public, nonprofit, bribery organizations, bribery of business partners, bribes directly or indirectly.

According to international transparency in 2018, Indonesia obtained an index of 38 out of 100, which means that Indonesia ranked 89th out of 180 countries with the cleanest ranking or in other words, the level of corruption in Indonesia was quite high, which was ranked 89th out of 180 countries.

For Southeast Asia, Indonesia ranks fourth after Singapore, Brunei Darussalam and Malaysia. When viewed from the cleanest country of corruption in the world, Indonesia occupies 80 of 168 countries in 2015 (CPI corruption performance index, 2015). Indonesia is still far below Malaysia which ranks 50th and Singapore ranked 8 th as the cleanest country from corruption. Looks like in the picture below.

Fraud have become one of the obstacles of investment in Indonesia. This is supported by the results of the World Economic Forum Survey of business players revealing a number of main factors inhibiting investment in Indonesia, where of the 16 factors referred to WEF (world economic forum) places Fraud - corruption with the highest score, which is $13.8 \%$ as the main inhibiting factor investment in Indonesia.

Meanwhile in the public sector, corruption in Indonesia has become a phenomenal issue and interesting to discuss with cases that are currently developing in society. Since the collapse of the New Order era, people have become increasingly critical in looking at government policies that are laden with corrupt, collusion and nepotism practices, or what is often known as KKN (corruption, collusion and nepotism). This type of fraud often cannot be detected because the parties work together to enjoy the benefits (symbiotic mutualism) or are corporate, including the abuse of power / conflict of interest (conflict of interest), bribery (bribery), receipt of unauthorized / illegal (illegal gratuities) and extortion economically (economic extortion).

Corruption itself has now been seen as the root cause of national problems, such as high economic costs, noncurrent economic growth, and investment barriers. There are government institutions such as BPK (Supreme Audit Agency), BPKP (Financial and Development Supervisory Agency), Inspectorate, KPK (Corruption Eradication Commission), NGOs (Non-Governmental Organizations) and ICW (Indonesian Corruption Watch), and even made Law Number 31 years 1999 concerning the Eradication of Corruption Crime in conjunction with Law Number 20 of 2001 concerning Eradication of Corruption Crimes has not succeeded in resolving the problem of rampant corruption.

This can be proven by we see corruption cases by type of case the top five (top five) of the most dominant corruption cases occurred in Indonesia until 2018 is bribery, procurement of goods / services, misuse of funds, fees, and licensing. Bribery cases continue to consistently occupy the first position as corruption which most often occurs with the accumulation of 564 cases. Then in the second position is occupied by corruption cases in the procurement of goods and services with a total of 188 cases. The third, fourth and fifth positions are respectively occupied by misuse of the budget, fees, and permits with a total of 46, 25 and 23 cases respectively (kpk.go.id).

In terms of the value of losses, the comparison of the total number of corruption cases in 2016 and 2017, amounting to Rp1.45 trillion, the value of losses must be borne by the state due to the occurrence of corruption cases of 482 cases in 2016. Whereas for 2017, the amount of state losses increased rapidly to Rp 6.56 trillion as a result of the occurrence of 576 cases of corruption in 2017 (kpk.go.id).

Therefore, President Joko Widodo in 2016 felt the need to issue a Presidential Instruction related to the above phenomenon, namely Inpres No. 10 of 2016 concerning Actions to Prevent and Eradicate Corruption. One of the tools used in the implementation of this presidential instruction is SNI ISO37001, the Indonesian national standard issued by BSN which identically adopts ISO37001: 2016 " Anti Bribery Management Systems ". In the Presidential Instruction, BSN (national standardization body) received the mandate to take the Anti Corruption System Certification Initiation Actions to all existing business entities, both BUMN, BUMD and private. This shows that the government's commitment related to the practice of KKN prevention in Indonesia is very large.

Related to the study researchers wrote, form 374 PDAM that exist in Indonesia, there were several cases related to fraud, as shown in the table below. But specifically for the name of the PDAM which is the object of 
research, the authors refer to as Drinking Water Company

Table 1.1. Notes on PDAM Fraud Cases in Indonesia

\begin{tabular}{|c|c|c|}
\hline No & Case / Fraud Notes & $\begin{array}{c}\text { Impact / } \\
\text { Loss }\end{array}$ \\
\hline 1 & $\begin{array}{l}\text { PEKANBARU - Riau Regional Police detained three suspects in a suspected corruption } \\
\text { case of a PDAM pipeline transmission project in Indragiri Hilir (Inhil) Regency. One } \\
\text { suspect is always absent and is now issued a DPO letter. "We have issued a list of people } \\
\text { who were involved in the initials of HA who were involved in the alleged corruption of } \\
\text { the PDAM transmission pipeline. HA is always absent for questioning as a suspect," said } \\
\text { Riau Police Special Criminal Investigation Director (Dir Reskrimsus) Riau Police, Senior } \\
\text { Commissioner Gidion Arif Setiawan told reporters on Wednesday (10/24/2018), Gidion } \\
\text { explained, his party was currently hunting HA DPOs. A summons for an examination is } \\
\text { always ignored. "We continue to search for HA as a contractor. We have detained three } \\
\text { of his colleagues some time ago related to the alleged corruption of the PDAM pipeline } \\
\text { project which cost Rp3 billion," said Gidion. }\end{array}$ & Rp. 3 billion \\
\hline 2 & $\begin{array}{l}\text { PANGKALPINANG, KOMPAS.com - Two suspects in a corruption case in the } \\
\text { construction of the Merawang Bangka PDAM pipeline, the Bangka Belitung Islands, } \\
\text { gradually returned the Rp } 1.9 \text { billion in corruption money. However, they are still being } \\
\text { held by the prosecutors. Head of Penkum Penitum Kejati Bangka Belitung Islands Roy } \\
\text { Arland said, the suspects detained each had the initials RF alias Pepen and AL alias Judas. } \\
\text { The two men play a role as providers of goods and company owners. "Two suspects have } \\
\text { been officially detained since Monday (10/22/2018) and we are leaving them in Tunu } \\
\text { Pangkal Pinang Lapas Lapas," Roy said when confirmed by Kompas.com, Tuesday } \\
(10 / 23 / 2018) \text {. }\end{array}$ & $\begin{array}{l}\text { Rp. } 1.9 \\
\text { billion }\end{array}$ \\
\hline 3 & $\begin{array}{l}\text { DELISERDANG - The Deliserdang District Attorney General's Special Crimes Sector } \\
\text { Team secured five people related to the alleged corruption case of PDAM Tirtanadi, } \\
\text { Thursday (7/18/2019). The five people named as suspects are former officials at PDAM } \\
\text { Deliserdang Branch. They are, the Head of Finance of PDAM Tirtanadi Deliserdang } \\
\text { Branch of } 2015 \text { Mustafa Lubis; Head of Finance of PDAM Tirtanadi Deliserdang Branch } \\
\text { in } 2015 \text { Lian Syahrul; Head of PDAM Tirtanadi Deliserdang Branch in } 2015 \text { to } 2016 \\
\text { Achmad Askari; Expert Staff of PDAM Directors Bambang Kurnianto and former Head } \\
\text { of PDAM Tirtanadi DeliserdangPahmiuddin Branch. Head of the Deliserdang Kejari, } \\
\text { Harli Siregar said there was a mark-up or mark up in the check for withdrawals. Where } \\
\text { the withdrawal check does not match the issued voucher. "That resulted in a state loss of } \\
\text { Rp10.6 billion. Every check cashed by the Head of the Finance Division there was a } \\
\text { difference with the value requested by the Head of the Public Sector that had been } \\
\text { approved by Kacab," he explained accompanied by Kasi Intel Kejari Deliserdang, } \\
\text { Muhammad Iqbal and Kasi Pidsus Afriz Chair in his office. }\end{array}$ & $\begin{array}{l}\text { Rp. } 10.6 \\
\text { billion }\end{array}$ \\
\hline 4 & $\begin{array}{l}\text { Gorontalo - Former Director of Gorontalo District Drinking Water Company ( PDAM ) } \\
\text { Tari Ahmad, who was accused in a case of alleged corruption in the maintenance of } \\
\text { PDAM pipeline assets in 2010/2011, was convicted by the Board of Judges of the } \\
\text { Corruption Court of the Gorontalo District Court. Tari was considered by the Panel of } \\
\text { Judges to have enriched themselves and was charged with Article } 2 \text { of the Corruption Act } \\
\text { (Corruption) with a sentence of } 7 \text { years in prison, a fine of Rp } 200 \text { million in } 8 \text { months } \\
\text { imprisonment, as well as being obliged to compensate state losses of Rp } 3.1 \text { billion. }\end{array}$ & $\begin{array}{l}\text { Rp. } 3.1 \\
\text { billion }\end{array}$ \\
\hline 5 & $\begin{array}{l}\text { DRINKING WATER COMPANY - The Attorney General's Office determined that the } \\
\text { official commitment maker (PPK) of DRINKING WATER COMPANY had the initials } \\
\text { RTU as a suspect. He was named a suspect for extorting a contractor of Rp. } 1 \text { billion } \\
\text { "The Attorney General's Pidsus Investigator has determined the initials of the RTU as P } \\
\text { T. XYZ commitment maker (PPK) as a suspect in a case of alleged corruption in the abuse } \\
\text { of authority / power in his position or extortion by asking for Rp } 1 \text { billion from the } \\
\text { contractor," } \\
\text { said } \\
\text { a Center for Legal Information at the Attorney General's Office in his statement, Friday } \\
(4 / 1 / 2019) \text {. }\end{array}$ & Rp. 1 billion \\
\hline 6 & $\begin{array}{l}\text { DRINKING WATER COMPANY, there was a report through WBS (wistle blowing } \\
\text { system) on August 16, } 2019 \text { related to the abuse of authority and position of P2K }\end{array}$ & $\begin{array}{c}\text { Potential } \\
\text { and has been } \\
\text { investigated } \\
\text { by FKAP }\end{array}$ \\
\hline
\end{tabular}


In order to follow up on President Instruction No. 10 of 2016, then DRINKING WATER COMPANY started to implement, implement and even achieve ISO37001: 2016 certification which was held in November 2019. The main objective of DRINKING WATER COMPANY ISO37001: 2016 certified is zero fraud in the first year and zero near miss fraud in the $3^{\text {rd }}$ year of implementation.

For the phenomena that occur above, the author feels interested in conducting research and analysis of the influence of capability, opportunity, pressure and rationalization to occur this fraud at Drinking Water Company, specifically at the Directorate of Services and Managing Water Use.

The author hopes to then be able to provide input to Drinking Water Company in particular and PDAMs throughout Indonesia in general, so that it can improve company performance through improvement performance is related to fraud performance

\subsection{Research objective and question}

The objective of this research is to develop a model to determine the determinants of the dominant factors of diamond fraud.

1. Know and explain the effect of rationalization on fraud.

2. Know and explain the effect of pressure on fraud

3. Know and explain the effect of capability on fraud

4. Know and explain the effect of opportunities on fraud

5. Know and explain the effect of rationalization on opportunity.

6. Know and explain the effect of pressure on opportunities.

7. Know and explain the effect of capability on opportunities.

8. Know and explain the indirect effect of rationalization on fraud through opportunities.

9. Know and explain the indirect effect of pressure on fraud through opportunities.

10. Know and explain the indirect effect of capability on fraud through opportunities.

The author formulates the phenomena that occur at Drinking Water Company based on the background and identification of the problems that have been presented previously by using some quantitative research questions, among others:

1. Does rationalization affect fraud ?

2. Does pressure affect fraud?

3. Does capability affect fraud ?

4. Does the opportunity affect fraud ?

5. Does rationalization affect opportunity?

6. Does pressure affect opportunity?

7. Does capability affect opportunity ?

8. Does rationalization have an indirect effect on fraud through opportunity.

9. Does the pressure have an indirect effect on fraud through opportunities.

10. Does capabilities have an indirect effect on fraud through opportunities?

\section{Literature Review}

\subsection{Capability}

Capability is the personal traits and capabilities that play a major role which led to fraud actually occurred even with the presence of three other elements. Although there are three elements of the triangle fraud theory (pressure, opportunity, and rationalization), if there is no capability of the culprit, then fraud behavior will not occur. According to Hay (2013) in Shelton (2014), capability is the nature of individuals who commit fraud / fraud, which encourages them to look for opportunities and use them to commit fraud. This opinion states that in addition to environmental factors, behavioral factors are also considered as predictors of fraud. Capability can cause a very severe threat because the actors in the organization are people who have power, and have intelligence and understand the system within the organization. Perpetrators can commit white collar crime. This type of fraud has a very large and very significant threat to the organization.

The intelligence and knowledge of the actors about the system can be a point of weakness that can be exploited for perpetrators of fraud. Individual abilities consist of position in work (positioning), intelligence ability (intelligence), ability to influence others (coercion), self-confidence (ego), ability to cheat / lie (deceit), and the ability to stress management (stress management). Wolfe and Hermanson (2004) argue that:

"Many Frauds, especially some of the multibillion-dollar ones, would not have occurred without the right person with the right capabilities in place. Opportunity opens the doorway to Fraud, and incentive and Rationalization can draw the person toward it. But the person must have the Capability to recognize the open doorway as an Opportunity and to take advantage of it by walking through, not just once, but time and time again. Accordingly, the critical question is; Who could turn an Opportunity for Fraud into reality? "

This means that there is a lot of fraud that is generally large-scale is not possible if there are no specific people 
with special capabilities that exist in the company. Opportunity opens opportunity or entrance for fraud, while pressure and rationalization encourage someone to do Fraud. Three things that can be observed in predicting fraud are: 1). Official position or function in the organization. 2). the capacity to understand and utilize accounting systems and internal control weaknesses. 3). Convinced that he will not be detected or if caught he will come out easily, Wolfe and Hermanson (2004) explain the characteristics related to capability elements that are very important in the person of the perpetrators of fraud, namely:

a. Positioning

A person's position or function in an organization can provide the ability to create or take advantage of opportunities for fraud. Someone in a position of authority has more influence over a particular situation or environment.

b. Intelligence

The perpetrators of this fraud have a sufficient understanding and exploit the weaknesses of internal control and to use positions, functions, or authorized access to the greatest advantage.

c. Evidence / ego

The individual must have a strong ego and great confidence he will not be detected. General personality types include someone who is driven to succeed at all costs, selfish, confident, and often loves himself (narcissism). According to the Diagnostic and Statistical Manual of Mental Disorder, narcissistic personality disorders include the need to be admired and the lack of empathy for others. Individuals with this disorder believe that they are superior and tend to want to show their achievements and abilities.

d. Coercion

Frauders can force others to commit or hide fraud. An individual with a persuasive personality can more successfully convince others to go along with fraud or look the other way.

\subsection{Pressure}

Pressure is the desire of employees to act fraud due to pressure from internal and external parties. Usually the situational push / pressure arises because of financial problems, but can also occur due to other symptoms of pressure such as work pressure, lifestyle, and so forth. Wexley and Yuki (2003) state that dissatisfaction due to inadequate compensation or tedious work can also support incidents of theft by workers. From this explanation it can be concluded that employees who are dissatisfied with compensation tend to look for other income, in this case looking for other income by committing corruption. Another factor causing fraud related to motivation is organizational justice. Folger and Cropanzano (1998) define organizational justice as conditions of work that lead individuals to a belief that they are treated fairly or unfairly by their organizations. When individuals feel an injustice, their morale will drop, they will most likely leave their jobs, and may even take revenge on their organizations. Situational pressure can be illustrated by superiors 'authority as in the study of Murphy and Mayhew (2013) who examined the influence of superiors' authority to commit fraud on reporting fraudulent behavior. Murphy and Mayhew (2013) found that the presence of superior authority increases reporting fraudulent behavior. Sofyani and Pramita (2014) also found that conditions where there was a superior authority to commit fraud, coupled with threats (retaliation) from superiors if the orders were not carried out would make someone act to manipulate reports.

This pressure actually has two forms, namely:

a. Real form ( direct ) is the real life conditions faced by the perpetrators such as the habit of frequent gambling, party / clubbing, or financial problems.

b. The form of perception ( indirect ) is an opinion that is built by actors who encourage to commit fraud such as executive need.

In SAS (statement of auditing standard) No. 99, namely the standards issued by the AICPA (American Institute of Certified Public Accountants), there are four types of conditions that commonly occur in humans that cause pressure that can lead to fraud, namely:

a. Financial stability pressure, is the pressure associated with the stability of financial conditions.

b. Financial target, is the pressure that requires employees / employees to work in accordance with the target or even exceed the target set.

c. Personal financial need, is the pressure associated with the level of personal financial needs of a person in order to meet their needs.

d. External pressure, pressure originating from outside parties or third parties such as creditors, investors and regulators.

\subsection{Rationalization}

Association of Certified Fraud Examiners (ACFE) said that the factors which the third occurrence of a fraud is rationalization. In line large rationalization can be interpreted as an act justification by those who find themselves trapped in a bad situation. The perpetrator will find a reason to justify the crime for himself so that the actions he 
has done can be accepted by the community. According to Spillane (2003), rationalization is a lifestyle in society that is not in accordance with the principles that unite, indirectly rationalization provides a way to justify actions that are not in accordance with existing circumstances. A way of rationalizing that often happens is moving the basic truth parallel to improper achievements, but on the contrary this rationalization will only produce false selfesteem. Sociologists refer to the process by which an increase in the number of social actions takes place based on consideration of the efficiency of calculation rather than on motivation derived from morality, emotions, habits or traditions. As we know white collar crime or white collar crime has a characteristic lack of feelings or indifference of the perpetrators derived from a series of reasons or rationalization to free themselves from guilt that arises from their deviant behavior (Dellaportas, 2013). Rationalization is a weapon used by the perpetrators in denying all the mistakes or cheating they made in order to maintain their self-image.

According to Spillane (2003), rationalization is a lifestyle in society that is not in accordance with the principles that unite, indirectly rationalization provides a way to justify actions that are not in accordance with existing circumstances, for example: 1) actions to make families happy and people he loves, 2) the perpetrator's work period is quite long and he feels he should be entitled to more than he has now (position, salary, promotion, etc.). 3) The company has gained a very large profit and it does not matter if the actor takes a small part of the profit.

According to Annisya and Asmaranti (2016) rationalization is behavior that tolerates or allows individuals to commit fraud and assumes that such actions are normal and reasonable. Rationalization is also defined as a form of attitude and thought process that is based on various moral considerations of individual employees to rationalize cheating behavior by using various reasons as a form of justification for their behavior (Apriadi, 2014). Then Ratmono et al., (2014) states that rationalization is related to a person's attitude and personality in justifying ethical values that actually deviate.

Several studies has shown that a significant effect on fraud (Asare et al., 2015; Purwanto et al., 2017; Peprah, 2018). In this study the perpetrators or employees rationalize that they are not being dishonest, or that employees value what they need more than honesty and integrity. The tendency to commit fraud depends on ethical values and on the personal circumstances of each employee. This means that the higher the employee's rationalization of fraud, the higher the probability of committing fraud. The more employees commit fraud, the more fraud is considered as a common thing by employees

\subsection{Opportunity}

Opportunities are opportunities that allow fraud to occur which is usually caused by the absence of supervision, internal supervision of a weak / ineffective organization, and abuse of authority. accounting rules and internal controls affect reporting fraud. The better internal control of government bureaucracy, the lower the government accounting fraud. Other proxies used to measure the opportunity variable against fraud are law enforcement and enforcement. Law enforcement is a form of concrete action by legal subjects to applicable law, namely by obeying the laws in a country. Most people understand the law, but do not obey it. So in this case it takes public awareness. Public awareness will arise if law enforcement can run properly. Good law enforcement is expected to reduce fraud in the government sector. This opportunity exists because the perpetrators believe that their activities will not be detected.

Cressey argues, there are two components of perception about this opportunity. First, general information , which is knowledge that positions that contain trust or trust, can be violated without consequences. This knowledge is obtained from what is heard or seen, as from the experience of others who commit fraud not being found out or not being punished. Second, the technical skills or expertise needed to carry out the fraud (Tuanakotta, 2012).

Priantara (2013) argues that there are two factors that can increase the chances of someone cheating, namely (Ulfah, et al., 2017):

a. A weak internal control system, for example lacking or no audit trail, so that tracking cannot be carried out, the inadequacy and ineffectiveness of control activities in risky areas and business processes. Including the ineffectiveness of control is the existence of excessive trust received by the perpetrators of fraud from the employer or the owner of the company or the supervisor is not disciplined to supervise.

b. Organizational governance is bad as there is no high commitment and good role model from the layers of management, management attitude is negligent, apathetic, or indifferent and fails to discipline or impose sanctions on perpetrators of fraud or omission of unethical or fraud perpetrators.

Opportunities have a significant influence on fraud (Dorminey et al., 2010; Albrecht et al., 2012; Adi et al., 2016; Yogo, 2016; Peprah, 2018). It can be seen from this research that Drinking Water Company employees do not feel they have a combination of circumstances and conditions that allow them to commit fraud or fraud. This is because regulations related to fraud or fraud can provide fairly severe sanctions, this also indicates that regulations related to fraud or fraud are running well. Strict supervision, the leadership checks every job given by students, so that it does not create opportunities for Drinking Water Company employees to commit fraud. The lower the opportunities obtained by Drinking Water Company employees, the less likely it is to commit fraud 


\section{Research Model and Hypothesis}

\subsection{Research model}

According to Uma Sekaran in Sugiyono (2005) suggested that the framework of thinking is a conceptual model of how theories relate to various factors that have been identified as important.

A good frame of mind will theoretically explain the interrelation between variables to be studied. So theoretically it is necessary to explain the relationship between independent and dependent variables, if there are intervening variables in the study, then it must also be explained why these variables are included. Framework for Research The research in this research can be seen in Figure 1, below this.

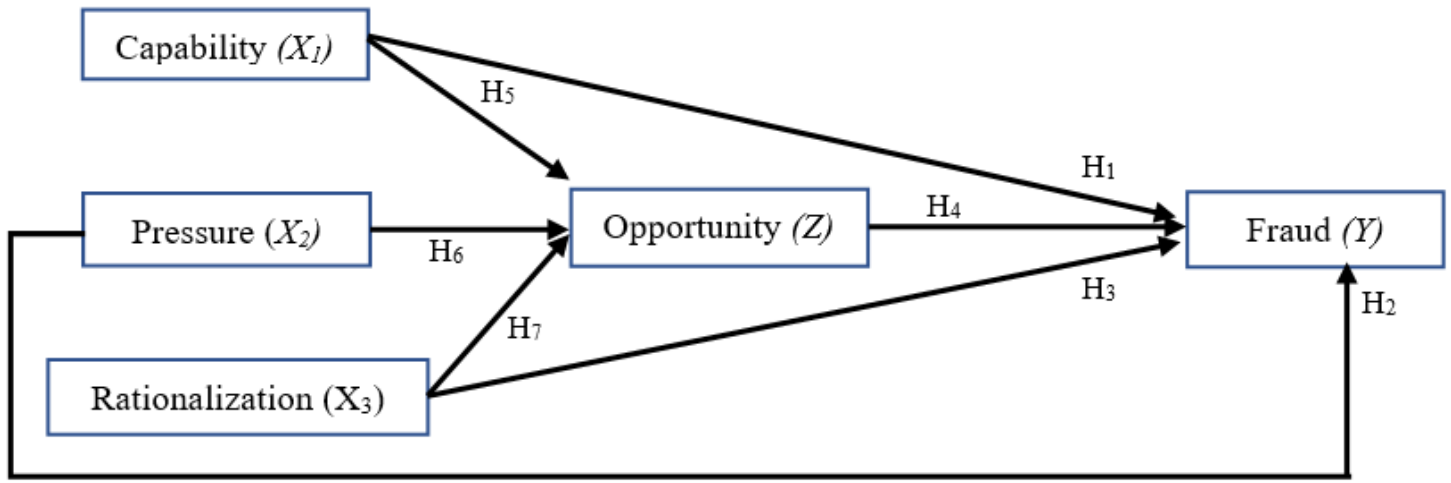

Figure 3.1. Research Framework for Thinking

In this study there are three dependent variables (exogenous) namely Capability (X1), Pressure (X2) and Rationalization (X3), and two independent variables (endogenous) namely Opportunity (Z) and Fraud (Y)

\subsection{Hypothesis}

The hypothesis is a temporary answer to the formulation of the assessment problem, therefore the formulation of the research problem is usually arranged in the form of sentence questions. It was said temporarily, because the answers given were only based on relevant theories, not yet based on empirical facts obtained through data collection. So the hypothesis can also be stated as a theoretical answer to the formulation of a research problem, not yet an empirical answer.

Based on the development of the thought framework model above, the hypotheses in the above research are:

1. Capability has a significant effect on fraud.

2. Pressure significantly influences fraud

3. Rationalization has a significant effect on fraud.

4. Opportunities significantly influence fraud.

5. Capability has a significant effect on Opportunity .

6. Pressure has a significant effect on Opportunity.

7. Rationalization has a significant effect on Opportunity

8. Capability has a significant indirect effect on fraud through opportunity.

9. Pressure has a significant indirect effect on fraud through opportunity

10. Rationalization has a significant indirect effect on fraud through opportunities.

\section{Methodology}

The study was conducted in Indonesia, namely in a drinking water company in Surabaya. This research uses a quantitative approach that is reviewing the facts that have occurred. A quantitative approach is used where the researcher wants to describe variations of a phenomenon, situation, problem and existing issues and interrelations. Data needed in this study includes primary data and secondary data. Primary data is data obtained directly by researcher data collection in the field and not obtained from others (Masydhudzulhak et.al, 2015: 37). This data is obtained directly by using a questionnaire through the use of Google forms. Secondary data is data that has been collected previously obtained from journals, related articles, standards and websites.

In addition, it was also obtained from companies related to this research. Data for this study were obtained directly from the results of the questionnaire responses that were submitted to all respondents or employees of Drinking Water Company.

The population in this study were employees who worked at the Directorate of Services and Managing Water Use, totaling 203 people. Population representation by sample in research is an important requirement for generalization.

To analyze the data used the Structural Equation Modeling (SEM) of the Lisrel 8.8 statistical software package in the model and hypothesis testing. The structural equation model / SEM is a collection of statistical 
techniques that allow the simultaneous testing of a series of relatively "complex" relationships (Ferdinand, 2006). By using LISREL, the pattern of data linkages will be more easily identified, so that the influence of pressure, capability and rationale and opportunities can be measured in a structured way.

\section{Result}

\subsection{Validity test}

Validity testing is used to measure valid or invalid results of a questionnaire that has been distributed to respondents. This test is done by looking at $r$ count (product moment value) compared to the value of $r$ table obtained from the degree of freedom $(\mathrm{df}=\mathrm{n}-2)$, where $\mathrm{n}$ is the number of respondents as many as 203 then the value of $\mathrm{r}$ table can be obtained through Pearson product moment table with $\mathrm{df}$ (degree of freedom) $=\mathrm{n}-2$, so $\mathrm{df}$ $=203-2=201$. Then $\mathrm{r}$ table $=0.137$ with a significant level of 0.05 for each question, as shown in Table 5.1 below :

Table 5.1. Validity Test Results

\begin{tabular}{|c|c|c|c|}
\hline No & Indicator & $r$ count & Description \\
\hline \multirow[t]{5}{*}{1} & Capability & & \\
\hline & Question X1.1 & 0,921 & Valid \\
\hline & Question X1.2 & 0,906 & Valid \\
\hline & Question X1.3 & 0,752 & Valid \\
\hline & Question X1.4 & 0,893 & Valid \\
\hline \multirow[t]{5}{*}{2} & Pressure & & \\
\hline & Question X2.1 & 0.801 & Valid \\
\hline & Question X2.2 & 0.911 & Valid \\
\hline & Question X2.3 & 0.805 & Valid \\
\hline & Question X2.4 & 0.887 & Valid \\
\hline \multirow[t]{5}{*}{3} & Rationalization & & \\
\hline & Question X3.1 & 0.812 & Valid \\
\hline & Question X3.2 & 0.813 & Valid \\
\hline & Question X3.3 & 0.929 & Valid \\
\hline & Question X3.4 & 0.862 & Valid \\
\hline \multirow[t]{5}{*}{4} & Opportunity & & \\
\hline & Question Z.1 & 0.742 & Valid \\
\hline & Question Z.2 & 0.903 & Valid \\
\hline & Question Z.3 & 0.888 & Valid \\
\hline & Question Z.4 & 0.787 & Valid \\
\hline \multirow[t]{4}{*}{5} & Fraud & & \\
\hline & Question Y.1 & 0.919 & Valid \\
\hline & Question Y.2 & 0.855 & Valid \\
\hline & Question Y.3 & 0.872 & Valid \\
\hline
\end{tabular}

\subsection{Reliability Test}

The reliability test in this study uses the decision making criteria as stated by Ghozali (2016), ie if the reliability coefficient $>0.7$ then the question is declared reliable. Conversely, if the reliability coefficient $\leq 0.7$ then the question is declared unreliable. The reliability test results in this study can be seen in the table below.

Table 5.2. Summary of Reliability Tests

\begin{tabular}{|c|c|c|c|}
\hline Variable & Reliability Coefficient & Critical point & Description \\
\hline Capability & 0,884 & 0,7 & Reliable \\
\hline Pressure & 0,867 & 0,7 & Reliable \\
\hline Rationalization & 0,853 & 0,7 & Reliable \\
\hline Opportunity & 0,850 & 0,7 & Reliable \\
\hline Fraud & 0,840 & 0,7 & Reliable \\
\hline
\end{tabular}

\subsection{Structural Equation Modeling Test (SEM)}

\section{Model Measurement Test}

The stage in SEM analysis technique is the measurement model stage. The measurement model is used to measure the dimensions that form a factor. Estimation technique used in SEM calculation is to use maximum likelihood . But before forming a full SEM model, testing of the factors that make up each variable will first be done. Testing will be done by looking at the results of standardized regression weight in the Lisrel output table. If there is an 
estimate value of the indicators that have an estimated value $<0.5$ then the indicator cannot describe the construct.

Exogenous Constructs Measurement Model

The measurement model test results for the exogenous construct can be seen through the loading factor coefficient values for each indicator presented in the following table.

Table 5.3. Exogenous Construction Measurement Model

\begin{tabular}{|c|c|c|c|c|c|c|}
\hline $\begin{array}{c}\text { Latent } \\
\text { Variable }\end{array}$ & $\begin{array}{l}\text { Variable } \\
\text { manifest }\end{array}$ & $\Lambda$ & $\lambda^{2}$ & e & CR & VE \\
\hline \multirow{4}{*}{ Capability } & $\mathrm{C} 1$ & 0,957 & 0,916 & 0,084 & \multirow{4}{*}{0,900} & \multirow{4}{*}{0,620} \\
\hline & $\mathrm{C} 2$ & 0,854 & 0,729 & 0,271 & & \\
\hline & C3 & 0,555 & 0,308 & 0,692 & & \\
\hline & $\mathrm{C} 4$ & 0,921 & 0,848 & 0,152 & & \\
\hline \multirow{4}{*}{ Pressure } & T1 & 0,707 & 0,500 & 0,500 & \multirow{4}{*}{0,875} & \multirow{4}{*}{0,638} \\
\hline & $\mathrm{T} 2$ & 0,898 & 0,806 & 0,194 & & \\
\hline & T3 & 0,724 & 0,524 & 0,476 & & \\
\hline & $\mathrm{T} 4$ & 0,849 & 0,721 & 0,279 & & \\
\hline \multirow{4}{*}{ Rasionalization } & R1 & 0,701 & 0,491 & 0,509 & \multirow{4}{*}{0,888} & \multirow{4}{*}{0,670} \\
\hline & $\mathrm{R} 2$ & 0,715 & 0,511 & 0,489 & & \\
\hline & R3 & 0,954 & 0,910 & 0,090 & & \\
\hline & R4 & 0,875 & 0,766 & 0,234 & & \\
\hline
\end{tabular}

Note: $\lambda=$ nilai faktor loading, $\mathrm{e}=$ error, $\mathrm{CR}=$ composite reliability, $\mathrm{VE}=$ variance extracted

The table above shows that the loading factor $(\lambda)$ value for each manifest variable is greater than 0.5 . This means that each manifest variable is declared valid in forming an exogenous construct. Then the value of $C R$ (construct reliability) must be above 0.7 and VE (variance extracted) must be above 0.5 already fulfilled so that it can be concluded that all exogenous constructs have good construct validity and reliability.

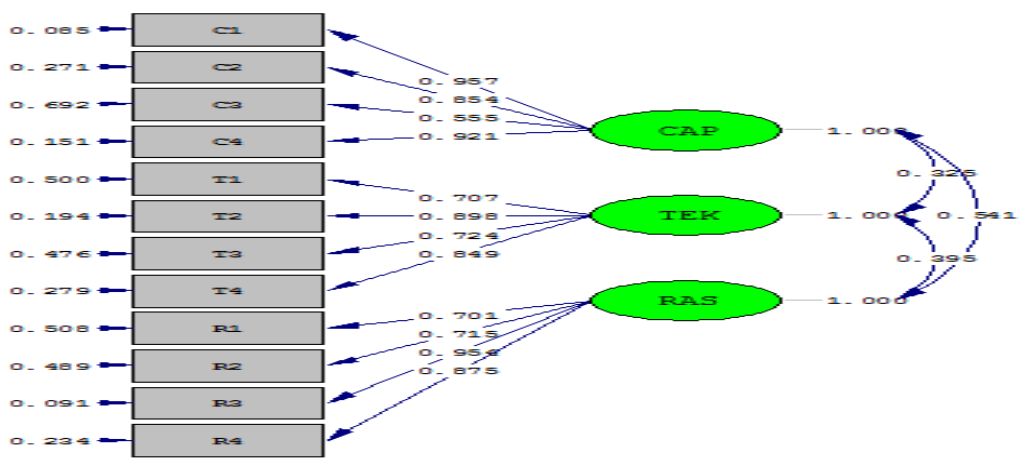

Figure 5.1. Model of Measurement of Exogenous Constructions

Measurement Model of Endogenous Constructions

Measurement model test results for endogenous constructs can be seen through the loading factor coefficient value for each indicator presented in the following table:

Table 5.4. Endogenous Construction Measurement Models

\begin{tabular}{|c|c|c|c|c|c|c|}
\hline $\begin{array}{c}\text { Latent } \\
\text { Variable }\end{array}$ & $\begin{array}{l}\text { Variable } \\
\text { manifest }\end{array}$ & $\lambda$ & $\lambda^{2}$ & e & CR & VE \\
\hline \multirow{4}{*}{ Peluang } & P1 & 0,738 & 0,545 & 0,455 & \multirow{4}{*}{0,859} & \multirow{4}{*}{0,565} \\
\hline & P2 & 0,925 & 0,856 & 0,144 & & \\
\hline & P3 & 0,793 & 0,629 & 0,371 & & \\
\hline & $\mathrm{P} 4$ & 0,637 & 0,406 & 0,594 & & \\
\hline \multirow{3}{*}{ Fraud } & F1 & 0,901 & 0,812 & 0,188 & \multirow{3}{*}{0,871} & \multirow{3}{*}{0,693} \\
\hline & F2 & 0,819 & 0,671 & 0,329 & & \\
\hline & F3 & 0,773 & 0,598 & 0,402 & & \\
\hline
\end{tabular}

Note : $\lambda=$ nilai faktor loading, $\mathrm{e}=$ error, $\mathrm{CR}=$ composite reliability, $\mathrm{VE}=$ variance extracted

The table above shows that the loading factor $(\lambda)$ value for each manifest variable is greater than 0.5 . This means that each manifest variable is declared valid in forming an endogenous construct. Then the value of CR (construct reliability) must be above 0.7 and VE (variance extracted) must be above 0.5 already fulfilled so that it can be concluded that the endogenous constructs have good construct validity and reliability. 


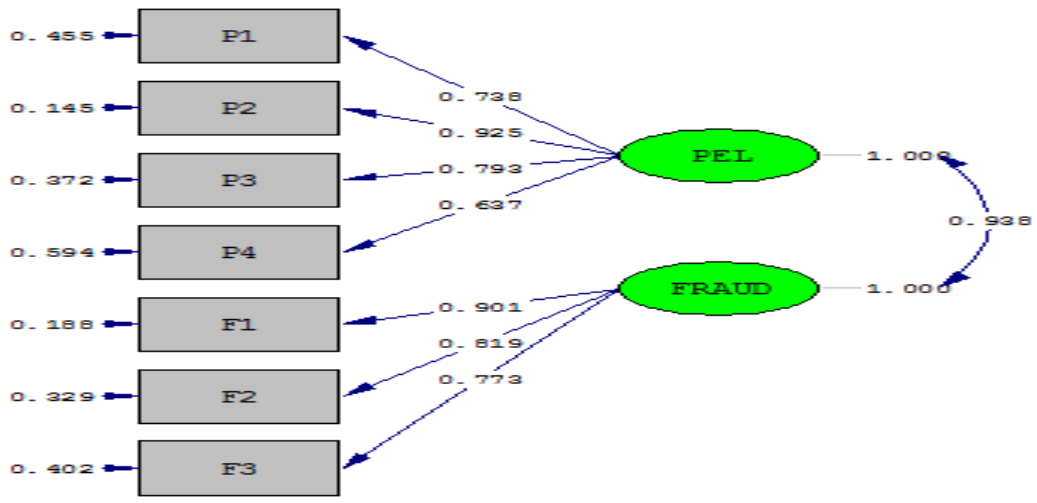

Figure 5.2. Endogenous Construction Measurement Model

\section{Structural Model}

As explained earlier that this study applies an analysis with Structural Equation Modeling (SEM) as an effort to test hypotheses. Model theoretically in this study have been described in Chapter II, where the research model aims to examine the influence of the variables in hypothesized.

In SEM analysis, there are two methods of using data input matrix types, namely the variance / covariance matrix and the correlation matrix. This analysis will use covariance matrix input for further estimation. The choice of input with a covariance matrix is because the covariance matrix has the advantage of providing valid comparisons between populations or different samples, which is sometimes not possible when using a correlation matrix model.

\section{Analysis of Structural Equation Models}

SEM analysis uses Lisrel software. The results of structural modeling can be seen in the following figure:

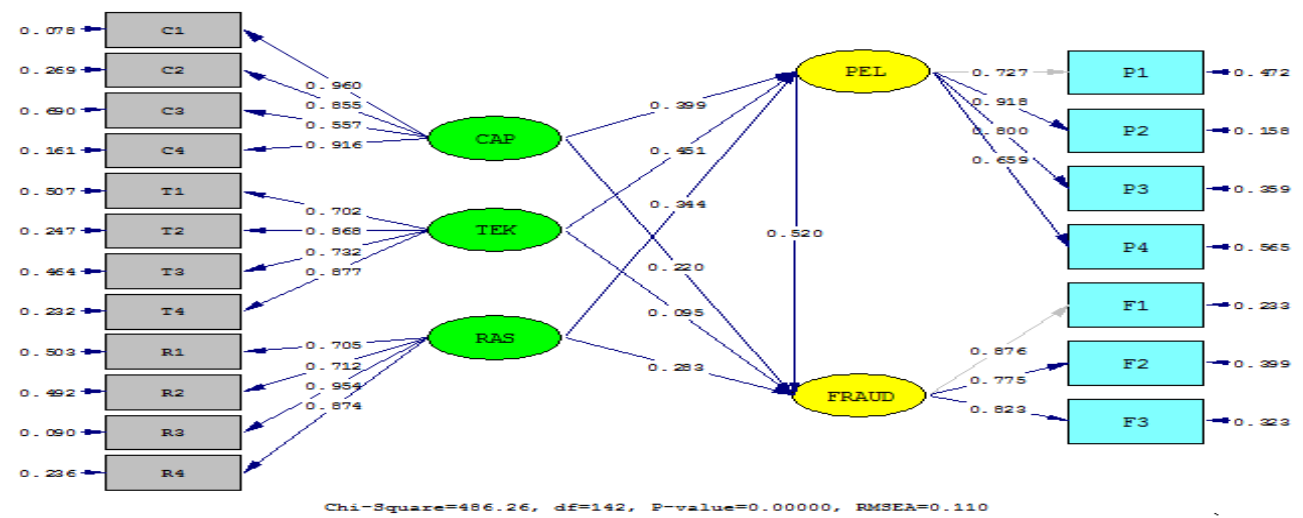

Figure 5.3. Standardize Structural Model

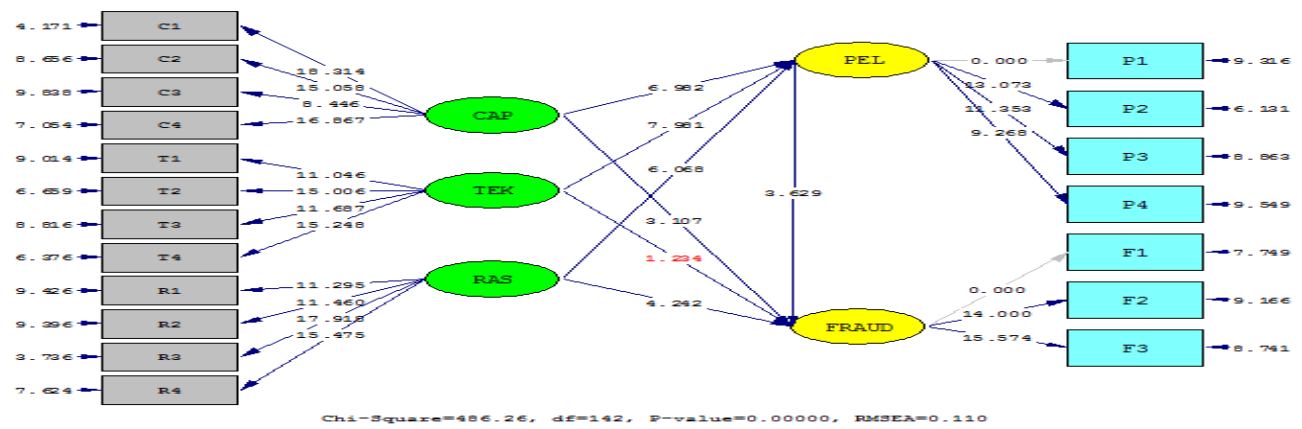

Figure 5.4. Path diagram and t-value

Figures 5 and 6 show the relationship between the variables used in the study and the $t$ value which indicates the significance value of the influence between the variables formed.

Based on the picture above we get the following structural equation:

1. Opportunity $=0,399 * \mathrm{CAP}+0,451 * \mathrm{TEK}+0,344 * \mathrm{RAS}$, Errorvar. $=0,136, \mathrm{R}^{2}=0,864$

2. Fraud $=0,520 \mathrm{PEL}+0,220 * \mathrm{CAP}+0,095 * \mathrm{TEK}+0,283 * \mathrm{RAS}$, Errorvar. $=0,040, \mathrm{R}^{2}=0,960$ 


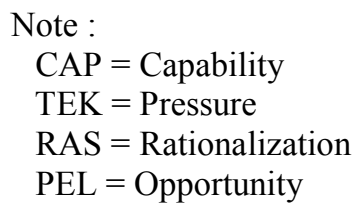

From the first equation it can be explained that the direction of the relationship of Capability, Pressure and rationalization with Opportunities is positive. The total effect of the first equation is $86.4 \%$. While in the second equation the direction of the relationship between Capability, Pressure, Rationalization and Opportunity with Fraud is positive with a total influence of $96.0 \%$.

Model Suitability Test (Goodness of Fit)

The Goodness of fit criteria of the structural equation model above is presented in the following table:

Table 5.5. Goodness of Fit Testing Research Models

\begin{tabular}{|c|l|c|c|c|}
\hline No. & \multicolumn{1}{|c|}{$\begin{array}{c}\text { Goodness of Fit } \\
\text { Index }\end{array}$} & $\begin{array}{c}\text { Cut-off } \\
\text { Value }\end{array}$ & Result & Conclusion \\
\hline 1 & Significant Probability & $\geq 0,05$ & 0,000 & Bad Fit \\
2 & RMSEA & $\leq 0,08$ & 0,060 & Good Fit \\
3 & GFI & $\geq 0,90$ & 0,904 & Good Fit \\
4 & AGFI & $\geq 0,90$ & 0,847 & Marginal Fit \\
5 & RFI & $\geq 0,90$ & 0,964 & Good Fit \\
6 & NFI & $\geq 0,90$ & 0,975 & Good Fit \\
7 & CFI & $\geq 0,90$ & 0,989 & Good Fit \\
8 & NNFI & $\geq 0,90$ & 0,989 & Good Fit \\
9 & IFI & Good Fit \\
\hline
\end{tabular}

Of the 9 indexes, only 1 stated that the model had a bad match, the rest stated that the model had a good match. So from this it follows that the model has a good fit. The cut off value from determining the fit model is if from the criteria at least seven criteria are declared fit.

\section{Hypothesis test}

The next goal in the analysis of structural models is to estimate the parameters of influence between variables, which at the same time will also prove the research hypothesis. The results of testing the hypothesis can be explained as follows. The results of hypothesis testing can be summarized from the results of parameter estimation from SEM analysis as shown in the following table:

Table 5.6. Summary of Hypothesis Tests

\begin{tabular}{|c|l|l|c|c|c|c|c|}
\hline \multicolumn{3}{|c|}{ Variable } & Beta & SE & T Value & t table & Description \\
\hline CAP & $-->$ & Fraud & 0,220 & 0,701 & 3,107 & 1,96 & Significant \\
\hline PRESS & $-->$ & Fraud & 0,095 & 0,077 & 1,234 & 1,96 & Not Significant \\
\hline RAS & $-->$ & Fraud & 0,283 & 0,076 & 4,242 & 1,96 & Significant \\
\hline OPP & $-->$ & Fraud & 0,520 & 0,143 & 3,629 & 1,96 & Significant \\
\hline CAP & $-->$ & Opportunity & 0,399 & 0,057 & 6,982 & 1,96 & Significant \\
\hline PRESS & $-->$ & Opportunity & 0,451 & 0,057 & 7,981 & 1,96 & Significant \\
\hline RAS & $-->$ & Opportunity & 0,344 & 0,057 & 6,068 & 1,96 & Significant \\
\hline
\end{tabular}
variable

While the following table 8 is a summary of the estimation results for the effect of opportunity as a mediating

Table 5.7. Summary of estimation results for mediation variables

\begin{tabular}{|c|c|c|c|c|c|c|}
\hline \multirow{2}{*}{$\begin{array}{c}\begin{array}{c}\text { Rank of } \\
\text { intervening }\end{array} \\
1 \\
\end{array}$} & \multicolumn{3}{|c|}{ Variabel } & \multirow{2}{*}{$\begin{array}{c}\text { T value } \\
3,304\end{array}$} & \multirow{2}{*}{$\begin{array}{c}\text { t table } \\
1,96 \\
\end{array}$} & \multirow{2}{*}{$\begin{array}{c}\text { Description } \\
\text { Mediation }\end{array}$} \\
\hline & Pres & Opp & Fraud & & & \\
\hline 2 & Cap & Opp & Fraud & 3,227 & 1,96 & Mediation \\
\hline 3 & Ras & Opp & Fraud & 3,115 & 1,96 & Mediation \\
\hline
\end{tabular}

Based on the table above and the results of the descriptive analysis can be stated as follows:

1. Almost all variables consisting of pressure, rationalization and fraud are in the high category, while the capability and opportunity variables are in the sufficient category

2. The first hypothesis is acceptable, because capability has a significant relationship with fraud. This shows that fraud can occur because of the capability of employees at Drinking Water Company

3. The second hypothesis cannot be accepted, because pressure has insignificant relationship with fraud. This shows that fraud cannot occur simply because of pressure on employees at Drinking Water Company

4. The third hypothesis can be accepted, because rationalization has a significant relationship with fraud. 
This shows that fraud can occur because of the rationalization of employees at Drinking Water Company

5. The fourth hypothesis can be accepted, because opportunities have a significant relationship with fraud. This shows that fraud can occur because of the opportunities for employees at Drinking Water Company

6. The fifth hypothesis is acceptable, because capability has a significant relationship with opportunity. This shows that opportunities can occur because of the capability of employees at Drinking Water Company

7. The sixth hypothesis is acceptable, because pressure has a significant relationship with opportunity. This shows that opportunities can occur only because of pressure on employees at Drinking Water Company

8. The seventh hypothesis is acceptable, because rationalization has a significant relationship with opportunity. This shows that opportunities can occur due to the rationalization of employees at Drinking Water Company

9. The eighth, nine and ten hypotheses are acceptable, because opportunities are able to mediate the capability, pressure and rationalization of Fraud. This shows that Fraud can occur with the presence of capability, pressure and rationalization mediated by opportunities for employees at Drinking Water Company.

\section{Finding and Discussion \\ Effect of Capability to Fraud.}

The results of this study indicate that there is a positif effect of the Capability variable on Fraud variable. This is also consistent with the researchers' initial assumptions that refer to previous theory and research, where Capability is personal traits and abilities that play a major role that causes fraud to actually occur even with the presence of three other elements. According to Hay (2013) in Shelton (2014), capability is the nature of individuals who commit fraud, which encourages them to look for opportunities and use them to commit fraud. So from this linkage and being connected with the results of existing studies it is evident that the capability will affect fraud.

This was also reinforced by several studies which stated that Capabiliti had a positive and significant effect on the Fraud variable (Wolfe \& Hermanson, 2004; Omar and Mohamad, 2010; Enofe et al., 2016; Peprah, 2018; Fitri and Nadirsyah, 2019). This is because employees are accustomed to cheating and do not have specific strategies in committing fraud. Personal characteristics and employee abilities play a major role in committing fraud. In this study employees have supporting elements in abilities as described by Wolfe and Hermanson (2004). Employees have the intelligence to see opportunities to commit an act of fraud because of the rules that are applied. Employees have high egos, so they can coerce others and also have the ability to manage stress when committing fraud. This finding also has implications that to overcome the occurrence of fraud can be done by overcoming capabilities that encourage someone to look for and take advantage of opportunities to commit fraud.

\section{Effects of Pressure on Fraud}

The results of this study indicate that there is a positive effect but not significant of the pressure variable on the Fraud. While the researchers' initial assumptions that refer to previous theories and research, where Pressure is the desire of employees to act fraud because of pressure from internal and external parties. Usually the situational push/pressure arises because of financial problems, but can also occur due to other symptoms of pressure such as work pressure, lifestyle, and so forth. However, from this connection and related to the results of existing research it is not proven that pressure will affect fraud.

This is also prove by some research (Peprah, 2018; Fitri and Nadirsyah, 2019). In this study the pressure does not affect the behavior of fraud or fraud, meaning that the employees of Drinking Water Company do not feel any pressure to commit fraud. There is no main reason that causes Drinking Water Company employees to commit an act of fraud due to pressure. Drinking Water Company employees understand SOTK (organizational structure and work procedures) or better known as job description, company culture / company values that have been implemented well, there is a mechanism to measure employee satisfaction levels and a reporting system for employee behavior or relations between employees which is stated in the written system and is well socialized. This finding also has implications that to overcome Fraud cannot be done by reducing pressure on employees in the company. In other words there are still many other factors that can be considered for overcoming Fraud.

\section{Effects of Rationalization on Fraud.}

The results of this study indicate that there is a positif effect of the Rationalization variable on Fraud. This is also consistent with the researchers' initial assumptions that refer to previous theories and research, rationalization is a weapon used by the perpetrators in denying all mistakes or cheating made with the aim of maintaining their selfimage and assuming that these actions are normal and reasonable. Rationalization is also defined as a form of attitude and thought process that is based on various moral considerations of individual employees to rationalize cheating behavior by using various reasons as a form of justification for their behavior. So from the linkages and related to the results of existing research it is proven that rationalization will influence fraud.

This is also reinforced by several studies which state that rationalization has a significant effect on fraud 
(Asare et al., 2015; Purwanto and Mulyadi., 2017; Peprah, 2018). In this study the perpetrators or employees rationalize that they are not being dishonest, or that employees value what they need more than honesty and integrity. The tendency to commit fraud depends on ethical values and on the personal circumstances of each employee. This means that the higher the employee's rationalization of fraud, the higher the probability of committing fraud. The more employees commit fraud, the more fraud is considered as a common thing by employees. This finding also has implications that to overcome Fraud can be done by reducing or changing the rationalization of employees in the company.

\section{Effects of Opportunities on Fraud}

The results of this study indicate that there is a positif influence of the Opportunity variable on the Fraud. This is also consistent with the researchers' initial assumptions that refer to previous theories and research, where Opportunities are opportunities that enable fraud to occur which are usually caused by lack of supervision, internal oversight of a weak / ineffective organization, and abuse of authority. Accounting rules and internal controls affect reporting fraud. So that from this connection and connected with the results of existing research it is evident that the opportunity will influence the occurrence of fraud.

This is also reinforced by several studies which state that opportunities have a significant influence on fraud (Dorminey et al., 2010; Albrecht et al., 2012; Adi et al., 2016; Yogo, 2016; Peprah, 2018). It can be seen from this research that Drinking Water Company employees do not feel they have a combination of circumstances and conditions that allow them to commit fraud or fraud. This is because regulations related to fraud or fraud can provide fairly severe sanctions, this also indicates that regulations related to fraud or fraud are running well. Strict supervision, the leadership checks every job given by students, so that it does not create opportunities for Drinking Water Company employees to commit fraud. The lower the opportunities obtained by Drinking Water Company employees, the less likely it is to commit fraud. This finding also has implications that to overcome Fraud can be done by minimizing opportunities that occur within the company.

\section{Effect of Capability on Opportunities}

The results of this study indicate that there is an influence of the Capability variable to Opportunities. This is also in accordance with the initial assumption of researchers who refer to the theory and previous research, fraud will not occur without someone who has the capability to recognize opportunities. Many frauds that are typically in the billions of dollars may not occur if there is no particular person with certain expertise in the company. But one must have the capability to recognize open doors as opportunities and take advantage of what he has lived not once but many times. This finding also has implications that to narrow or even close opportunities in the occurrence of fraud can be done by overcoming or at least reducing the capability to see the opportunities that exist.

\section{Effects of Pressure on Opportunities}

The results of this study indicate that there is a positive influence of the pressure variable on opportunities. This is also consistent with the researchers' initial assumptions that refer to previous theories and research, where with the pressure it will spur someone to look for and even create opportunities. Opportunities will be seen from the aspect of the weakness of the financial system or the existing supervision. Although this pressure does not directly impact opportunities, because opportunities must be formed and sought based on one's abilities. As stated earlier that pressure is the desire of employees to act, whether there is pressure from internal or external parties. Usually the situational push/pressure arises because of financial problems, but can also occur due to other symptoms of pressure such as work pressure, lifestyle, and so forth. With this pressure, it will spur someone to look for and even create opportunities. Opportunities will be seen from the aspect of existing system weaknesses. Although this pressure does not directly impact opportunities, because opportunities must be formed and sought based on one's abilities. This finding also has implications that to narrow or even close opportunities in the occurrence of fraud can be done by overcoming the pressure on employees so that it does not raise the intention to look for opportunities.

\section{Effects of Rationalization on Opportunities}

The results of this study indicate that there is a positive effect of the Rationalization variable on Opportunities. This is also consistent with the researchers' initial assumptions that refer to previous theories and research that rationalization is related to one's attitude and personality in justifying ethical values that actually deviate and in the end an opportunity will be created. So this opportunity is considered as an answer to the attitude of rationalization that they do. So from this linkage and being connected with the results of existing research it is evident that the creation of opportunities occurs because of the rationalization of attitudes that occur. This finding also implies that to narrow or even close opportunities in the occurrence of fraud can be done by overcoming the rationalization or justification of employee attitudes so as not to create opportunities. 
The influence of capability, pressure and rationalization on Fraud is mediated by opportunity

The results of this study indicate that there are influences on the variables of capability, pressure and rationalization on Fraud through This means that the opportunity variable is able to mediate the influence of capability, pressure and rationalization on fraud. This shows that Fraud can occur with the presence of capability, pressure and rationalization mediated by opportunities for employees at Drinking Water Company

The above is very possible if seen in the setting of the research location, in this study the subject of Drinking Water Company is a government organization, where even though the employees are experiencing high pressure, because they continue to receive fixed salaries and benefits every month and feel comfortable, they don't even think about cheating because of the pressure. Although in reality, based on the results of a survey conducted there are known that there are employees who feel pressured when working, this may be due to strict government regulations related to violations or fraud.

Also based on the initial preliminary survey at Drinking Water Company there have been several cases related to Fraud that several indicators of each variable include opportunity variables with indicators of nature of industry, capability with indicators of position and level in organization, pressure with indicators of financial need personnel and rationalization with justification indicators that have values above $50 \%$ can encourage fraud.

Based on the results of previous studies from previous studies, the findings that can be presented as a result of the study are the Fraud of employees at Drinking Water Company is influenced by various factors namely: capability, pressure and rationalization which are mediated by opportunities. Based on the results of the study note that the pressure that has or does not affect the variable fraud. In summary, these findings can be described as a conceptual model produced in this study, namely: "Conceptualization and Prevention of Fraud through capability, pressure, rationalization and opportunities at Drinking Water Company "is novelty because this research has a renewal in the category of development (innovation).

\section{Conclusions}

\subsection{Practical implications.}

In reducing the fraud, we recommend that the drinking water company consider capability, rationalization and opportunity characteristics because these three variables have a significant influence on fraud. Therefore this drinking water company should analyze overtime these three variables such that these three variables can be adjusted. In reducing opportunities we also recommend that the this drinking water company consider capability, pressure and rationalization characteristics because these three variables have a significant influence opportunities.

\subsection{Theoretical contributions}

Capability has positive and significant effect on fraud. This research in line with the previous research on several studies which stated that Capabiliti had a positive and significant effect on the Fraud variable (Wolfe \& Hermanson, 2004; Omar and Mohamad, 2010; Enofe et al., 2016; Peprah, 2018; Fitri and Nadirsyah, 2019). Rationality has positive and significant effect on fraud. This is also reinforced by several studies which state that rationalization has a significant effect on fraud (Asare et al., 2015; Purwanto et al., 2017; Peprah, 2018). Rationality has positive and significant effect on fraud. This is also reinforced by several studies which state that opportunities have a significant influence on fraud (Dorminey et al., 2010; Albrecht et al., 2012; Adi et al., 2016; Yogo, 2016; Peprah, 2018).

\subsection{Limitations of research}

This study explores the lack of other variables that may affect the fraud, such as power and culture. Due to measurement of this study, which only applied in certain period, the result of the study may not be set up for longterm period. A longer period of study is necessary to respond if the conclusion of this study is still applicable for long-term. This research still has limitations both in the sources of journals and theories that have been available so that it is expected for those who want to conduct research using the same object and research variables in order to increase more sources and accurate references related to the issues raised.

\subsection{Future research direction}

Future studies are expected to be able to consider factors or other causes of fraud. Using several independent variables, different research methods and data collection techniques are expected to be able to produce better results than the results in this study. It is hoped that further research will be able to expand the subject not only to employees in the Drinking Water company but also to various sectors/industries. This is done in order to be able to see the level of fraud occurring in companies or organizations in various sectors.

\section{REFERENCES}

Adi, Moh Risqi Kurnia., Ardiyani, Komala, \& Ardianingsih, Arum. (2016). Analisis Faktorfaktor Penentu Kecurangan (Fraud) pada Sektor Pemerintahan (Studi Kasus pada Dinas Pendapatan Pengelolaan 
Keuangan dan Aset Daerah Kota Pekalongan). Jurnal Litbang Kota Pekalongan, Vol.10.

Albrecht, S.W., C. O. Albrecht., C. C. Albrecht, \& M. F. Zimbelman. (2011). Fraud Examination Fourth Edition. New York: South-Western Cengage Learning.

Annisya, M., \& Asmaranti, Y. (2016), Pendeteksian Kecurang Laporan Keuangan Menggunakan Fraud Diamond. Jurnal Bisnis Dan Ekonomi, Vol 23, No. 1.

Apriadi, Rangga Nuh. (2014). Determinan Terjadinya Fraud di Institusi Pemerintahan. Universitas Brawijaya Malang.

Asare, S. K., A. Wright, and M. F. Zimbelman. (2015). Challenges Facing Auditors in Detecting Financial Statement Fraud: Insights from Fraud Investigations. Journal of Forensic and Investigative Accounting, 7 (2), 63-112.

Dellaportas, Steven, (2013). "Conversations with inmate accountants: Motivation, opportunity and the fraud triangle," Accounting forum, Elsevier, vol. 37(1),

Dorminey J., A. S. Fleming., M. J. Kranacher and R. A. Riley, Jr. (2010). Beyond The Fraud Triangle: Enhancing Deterrence of Economic Crimes. The CPA Journal

Enofe, A. O., Egbe, M.E., and America, D. O. (2016). Internal control mechanism and fraud prevention in Nigeria public sector: An application of the new fraud diamond theory. Journal of Accounting and Financial Management, 2(1), 35-47

Ferdinand, A., (2006), Metode Penelitian Manajemen. Semarang: Badan Penerbit. Universitas Diponegoro

Fitri and Nadirsyah, (2019), Pengaruh Tekanan (Pressure), Kesempatan (Opportunity), Rasionalisasi (Rationalization), dan Kapabilitas (Capability) Terhadap Kecurangan Pengadaan Barang/Jasa di Pemerintahan Aceh Dengan Pemoderasi Budaya Etis Organisasi, Jurnal Ilmiah Mahasiswa Ekonomi Akuntansi-JIMEKA, 4(3), 412-427, 2581-1002.

Folger, R., and Cropanzano, R. (1998). Organizational Justice and Human. Resource Management. Beverly Hills, CA.: Sage.

Hay, L. (2013). The Changing Profile of Fraud. http://www.ohioscpa.com/mobile/currentnews/2013/03/13/thechanging-profile-offraud? $\mathrm{c}=1$.

Masydhudzulhak et.al, (2015), Memahami Penulisian Ilmiah dan Metodologi Penelitian. LP2S. Jakarta.

Murphy, R. P. and B.W. Mayhew. (2013). The Impact of Authority on Reporting Behavior, Rationalization and Affect. SSRN Electronic Journal.

Omar, Normah Binti Omar, and H. F. Mohamad Din. (2010). Fraud Diamond Risk Indicator: An Assessment of Its Importance and Usage. http://ieeexplore.ieee.org/ document/5773853/

Peprah, W.K. (2018). Predictive Relationships among the Elements of the Fraud Diamond Theory: The Perspective of Accountants, International Journal of Academic Research in Accounting, Finance and Management Sciences 8 (3): 141-148.

Priantara, Diaz. (2013). Fraud Auditing \& Investigation. Jakarta: Mitra Wacana Media.

Purwanto, Edy and Mulyadi, Jmv., (2017)." Kajian konsep diamond fraud theory dalam menunjang efektivitas pengadaan barang/jasa di pemerintah kota Bogor".Jurnal Manajemen Indonesia, Vol.17 no.3 Desember 2017

Ratmono, Dwi, et. al., (2014). "Dapatkah Teori Fraud Triangle Menjelaskan Kecurangan dalam Laporan Keuangan?”. SNA 17 Mataram, Lombok. Universitas Diponegoro.

Shelton, Austin M. (2014). Analysis of Capabilities Attributed to The Fraud Diamond. Undergraduate Honors Theses. Paper 213.

Sofyani, H. and Y. D. Pramita. (2014). Otoritas Atasan, Retaliasi dan Locus of Control sebagai Faktor-Faktor yang Memengaruhi Perilaku Manipulasi Laporan Realisasi Anggaran. Jurnal Reviu Akuntansi dan Keuangan, 3 (2), 415-506

Spillane, James J. (2003). Time Management : Pedoman Praktis Pengelolaan Waktu. Yogyakarta : Kanisius

Sugiyono, (2005), Memahami Penelitian Kualitatif. Bandung: Alfabeta

The ACFE (Association of Certified Fraud Examiners), (2000), Fraud examiners Manual, Third Edition. ACFE.

Tuanakotta, Theodorus M. (2012). Akuntansi Forensik dan Audit Investigatif. Jakarta: Salemba Empat.

Ulfah, M., Nuraina, E., \& Wijaya, AL (2017). Pengaruh Fraud Pentagon Dalam Mendeteksi Fraudulent Financial Reporting (Studi Empiris Pada Perbankan di Indonesia Yang Terdaftar Di BEI), Forum Ilmiah Pendidikan Akuntansi, Vol. 5 No. 1

Wolfe, D., and Hermanson, D. R. (2004). The fraud diamond considering four elements of fraud. The CPA Journal, $74(12), 38-42$

Yego, K. S. (2016). The impact of fraud in banking industry: A case of standard chartered bank. Degree of Master in Business Administration. United State International University, http://erepo.usiu.ac.ke/bitstream/handle/11732/2488/The\%20Impact\%.20of\%20Fraud\%20in\%20the\%20Ba nking\%20Industry.pdf?sequence $=1 \&$ is Allowed $=y$ 